\title{
Lidia Dudek
}

Oil and Gas Institute - National Research Institute

\section{Pore size distribution in shale gas deposits based on adsorption isotherm analyses}

\begin{abstract}
Experimental isotherm data obtained for the samples collected from a selected shale gas borehole at the depth from 2803 to 2834 meters for both Argon and Nitrogen analysis at $77.4 \mathrm{~K}$ are presented. The results are compared for the mean value of Pore Size Distribution (PSD) using BJH (Barret-Joyner-Halenda) algorithm for desorption curves with application of thickness curve based on Halsey equation and also on Faas correction. Pore Size Distributions (PSD) and their volumes are characterized and compared for both the BJH and DFT (Density Functional Theory) methods.
\end{abstract}

Key words: shale rock, adsorption, desorption, pore size distribution, capillary condensation, adhesion.

\section{Rozkłady wielkości porów w złożach typu shale gas na podstawie analiz izoterm adsorpcji}

Przedstawiono eksperymentalne dane izotermiczne otrzymane dla próbek pobranych z wybranego odwiertu w niekonwencjonalnym złożu gazu z głębokości od 2803 do 2834 metrów, dla analizy z użyciem argonu i azotu w temperaturze 77,4 K. Porównano wyniki dla średnich wartości Rozkładu Wielkości Porów (ang. pore size distribution, tj. PSD) używając algorytmu BJH (ang. Barret-Joyner-Halenda) dla krzywych desorpcji z użyciem krzywej grubości zgodnie z równaniem Halsey’a oraz zastosowaniem poprawki Faas. Scharakteryzowano i porównano rozkład wielkości porów (PSD) i odpowiednio zajmowanych przez nie objętości przy użyciu metod BJH i DFT (ang. Density Functional Theory).

Słowa kluczowe: skały łupkowe, adsorpcja, desorpcja, rozkład wielkości porów, kondensacja kapilarna, adhezja.

\section{Introduction}

Shale gas clayey-mudstone rocks create a formation containing hydrocarbon resources confined in a complex porous space which is not easy to characterise. The clayey-mudstone layers contain natural gas in its free form in micropores (diameter $d<2 \mathrm{~nm}$ ) within laminae (thickness $h<1 \mathrm{~cm}$ ) enriched in silica and other detrital components (rock and mineral clasts, hard organic debris created during weathering), as well as within natural fractures and microfractures $(h<1 \mathrm{~mm})$. They also contain natural gas adsorbed by insoluble organic matter and by clay minerals. The gas-bearing shales thus form a unique hydrocarbon system, where the same rock formation is the source rock, the reservoir rock and the seal rock, and the migration of gas occurs only in micro scale or does not take place at all (Fig. 1) [1, 2]. The accumulation of gas in this type of deposit is therefore associated not just with the classic inter-grain pores, but also with micropores $d<2 \mathrm{~nm}$ present in the organic matter, and with mesopores $(d=2 \div 50 \mathrm{~nm})$. The presence of micropores affects the values of the specific surface areas (expressed in $\mathrm{m}^{2} / \mathrm{g}$ of the material) and thus the associated amount of gas adsorbed on the surface of the pores. The larger the specific surface area, the more likely one can expect the predominance of micropores within the examined sample $[3,11]$. Porosity and pore size distribution (PSD) are other important parameters of a porous matter, which is why it is so crucial to properly develop a method for testing both porosity and microporosity. The pore size distribution can be obtained either via mercury porosimetry in the case of meso- and macropores, or through adsorption techniques for micro- and mesopores. The current limitations of a mercury porosimetry apparatus (pressure up to $60000 \mathrm{psi}$ ) theoretically make it impossible to measure pores smaller than $3.6 \mathrm{~nm}$, while the practical threshold is 
probably higher $[4,10]$. Adsorption techniques utilising nitrogen, argon, carbon dioxide, helium and methane are used for examinations of very small pores. The distribution of pore diameters may be then obtained by means of the BJH model (Barret-Joyner-Halenda) from the desorption curve, the DFT model (Density Functional Theory), as well as the NLDFT (Non-Localized DFT) and QSDFT (Quenched Solid Density Functional Theory) models (Fig. 1).

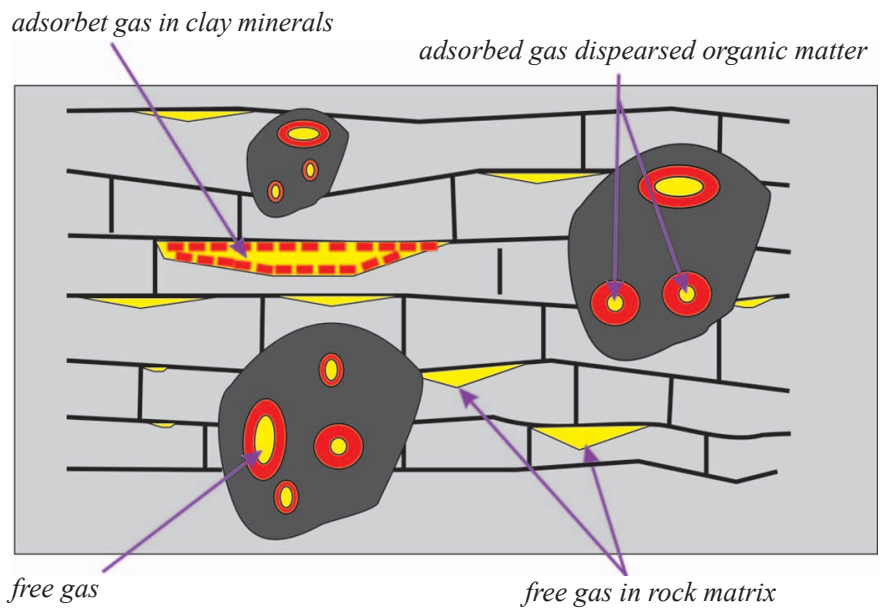

Fig. 1. Occurrences of gas in shaly sediments (after [9], modified)

\section{The BJH method}

The method developed by Barret-Joyner-Halenda (BJH) is used most frequently to determine the volume, size and distribution of the pores in the adsorbent. It is based on the assumption that within the relative pressure range of $0.4<p / p_{0}<0.98$, the phenomenon of capillary condensation takes place in mesopores (the gas is adsorbed in the pores as liquid at pressures close to (but below) the equilibrium vapour pressure). The increased pressure results in an increase in the thickness of the adsorbent layer on the pore walls, until the complete closure of the pores. Adopting the geometric model of pores in the adsorbent (cylindrical or slit-fracture), it is possible to calculate the total volume of the pores and their distribution. The pore radius can be calculated from the equation developed by Kelvin-Thomson:

$$
\frac{1}{r_{k, x}}-\frac{1}{r_{k, y}}=-\frac{R T}{\sigma V_{m}} \ln \left(\frac{p}{p_{0}}\right)
$$

where:

$r_{k, x}, r_{k, y}$ - meniscus curvature radiuses in two mutually perpendicular planes $x z, y z$,

$\sigma$ - surface tension of the liquid adsorbate,

$R$ - gas constant,

$T$ - absolute temperature,

$p_{0}$ - condensation pressure of adsorbate in laboratory conditions,

$p$ - absolute equilibrium pressure,

$V_{m}$ - molar volume of adsorbate.

Presenting the volume of pores as a function of radii determined via the Kelvin equation, in the form of $V=f\left(r_{k}\right)$, and subsequently conducting graphical differentiation of that curve, one obtains the so-called pore volume distribution curve. It takes the following form:

$$
d V / d r=f(r)
$$

\section{The DFT method (Density Functional Theory)}

The Barret-Joyner-Halenda and BET (Brunauer-Emmett-Teller) models often fail when distinguishing different morphologies of the porous structure, such as when taking into account the effects of microporosity and predicting the size of pores, which may be determined independently based on X-ray diffraction (XRD) and electron microscopy (TEM). The new nanomaterials and new experimental possibilities required the development of new theoretical methods for the analysis of the data [5]. Seaton et al. were the first to use the DFT method to calculate the parameters of a porous structure from the adsorption isotherms. Further improvement of this method was conducted by Lastoskie et al. [6], who used the NLDFT model (Non-Localized DFT) within the approximations of the smooth density of Tarazona for the modelling of nitrogen adsorption on carbons. Both papers considered pores to be infinite fractures, which is a conventional modelling projection of pores between the fragments of graphene in carbon. Almost at the same time, scientists from Mobil developed the MCM-41 mesoporous silicas with an ordered hexagonal structure of cylindrical channels, which for the first time provided verification of the theoretical methods of porous structure analysis, against credible experimental data [5].

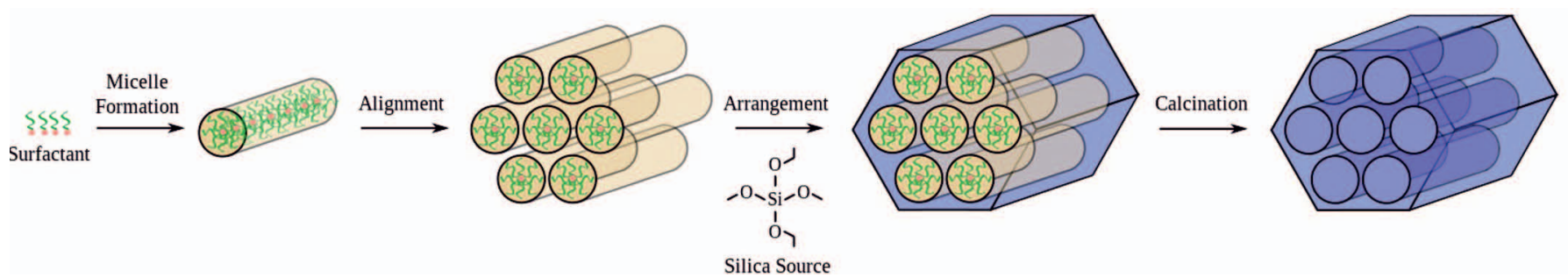

Fig. 2. Diagram of mesoporous silica MCM-41 with an ordered hexagonal structure of cylindrical channels 
The NLDFT model for adsorption of MCM-41 suggested and verified by Neimark and Ravikovitch [7] has become the basis for the further development of detailed DFT models, used for mesoporous and hybrid materials (being a uniform mixture of inorganic and organic components). Along with the set of the abovementioned factors, the NLDFT method became widely accepted within the scope in which it was recommended as a standard method by the International Organization for Standardization (ISO).

\section{The QSDFT method (Quenched Solid Density Functional Theory)}

Current applications of the NLDFT method (Non-Localized DFT) for carbon materials are based on a model of independent pores shaped as slit type fractures with perfect graphite walls. This model has a major disadvantage when used for carbons with highly diversified surfaces; starting from the width of the pores of several molecular diameters. Theoretical adsorption isotherms exhibit numerous steps associated with layer transitions resulting from the creation of a single layer, the second adsorbed layer, etc. The step-shaped experimental adsorption isotherms [13] are visible only at low temperatures for the adsorbed liquids on molecularly smooth surfaces (like mica or graphite). However, in carbon materials with diverse surface chemistry (e.g. some types of activated carbon) the inter-layer transitions are neutralised by the specific energetic and geometrical diversity of the actual surfaces. This discrepancy between the assumed theoretical isotherms in NLDFT models (i.e. lamination) and the experimental results may cause artificial gaps in the calculated pore size distribution. For instance, in the case of nitrogen at the temperature of $77 \mathrm{~K}$ on graphite, generation of the first layer in the first step of NLDFT occurs at the same pressure at which filling of pores having the width of $\sim 1 \mathrm{~nm}$ also takes place, resulting in a false gap in the histogram (Fig. 3). This problem is particularly visible for porous materials with a wide spectrum of pore sizes, which is typical for numerous materials with activated carbon.

Within the scope of a standard model of slit type fracture pores in carbons, the diversity in the thickness of pore walls was introduced, but this only slightly affected the improvement of the results compared to the standard approach of

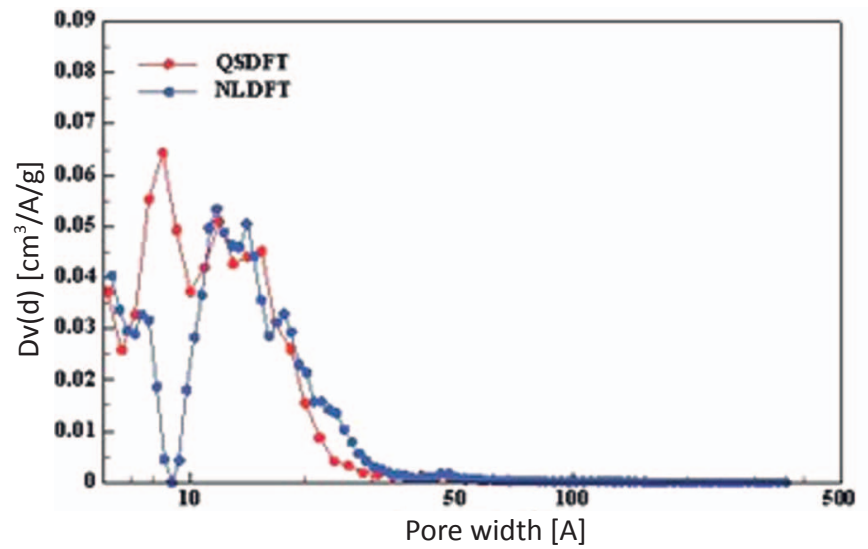

Fig. 3. A plot of a differential change in pore volume against the width of pores for the QSDFT and NLDFT methods [5]

NLDFT. Other approaches regarding the issue are based on adjusting the reference non-graphite carbon black isotherm, and the resultant NLDFT method proved to be beneficial (based on a limited number of examples) in mapping the distribution of pore sizes, without the false gap in the $\sim 1 \mathrm{~nm}$ range. Recently, Ravikovitch and Neimark [7] have suggested a new DFT model for adsorption in pores with diverse walls, called the Quenched Solid Density Functional Theory (QSDFT). This method allows for precise calculation of pore size characteristics, porosity and pore surface within the range between $0.35 \mathrm{~nm}$ and $40 \mathrm{~nm}$. Its main goal is the use of multi-component DFT, in which a solid is considered to be one of the components with a constant, spatially distributed density. In QSDFT, the solid is modelled using the spatial distribution of stable atoms and not as a source of an external potential field. This allows for direct consideration of the effects of diversity caused by surface roughness, thus improving the previous NLDFT models for carbons which assumed flat, structure-less graphite pore walls. The parameters of the fluid-fluid interaction have been determined in such a way which allows obtaining mass thermodynamic nitrogen equilibrium states at low temperatures. The model of a solid, the range of pore wall roughness (corrugation), and the parameters of solid-fluid interaction have been determined from the adjustment of experimental reference isotherms for graphite and non-graphite carbon black. The reference surface was selected for carbon black with a partial degree of graphitisation.

\section{The experimental part: argon and nitrogen porosimetry and the DFT method}

The measurements were conducted using the TriStar II 3020 apparatus (Micrometrics) at the temperature of liquid nitrogen, using nitrogen and argon as the adsorptive gases. Before commencing the measurements, each sample was weighed, and then dried at a temperature of $105^{\circ} \mathrm{C}$ for approximately 24 hours, and degassed at a temperature of $120^{\circ} \mathrm{C}$ in a flow stream of dry nitrogen. All samples were prepared for analysis in the same way, in order to obtain credible results, dependent solely on the used adsorbent, i.e. nitrogen and argon. The gas adsorption isotherm was presented 
as the volume of adsorbed gas in the $p / p_{0}$ function, where $p$-is the absolute equilibrium pressure, and $p_{0}-$ the nitrogen condensation pressure in laboratory conditions. The distribution of pore sizes was obtained from the desorption curve, using the BJH technique applying the thickness curve according to the Halsey equation and using the Faas correction. For this paper, calculations of all adsorption isotherm models were conducted after introducing the Tarazon NLDFT

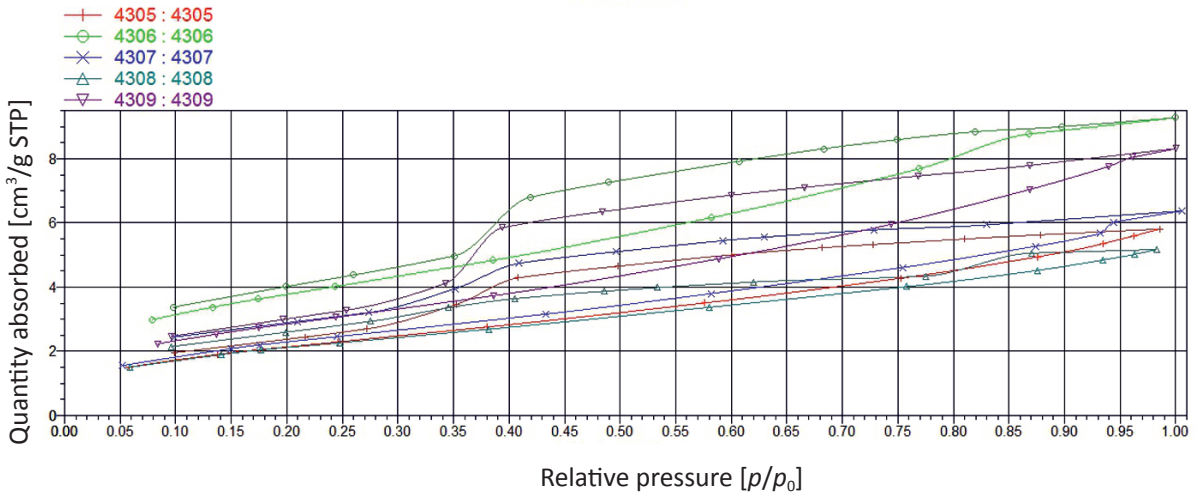
implementation described by Lastoskie et al. [6]. A slit fracture model of pores was adopted. Based on DFT, the changes in the increase of pore volume in relation to the pore width have been calculated. The results are presented in table 1 . In general, it can be concluded that argon at $77.4 \mathrm{~K}$ is always a better molecular probe than nitrogen at $77.4 \mathrm{~K}$, since it does not cause an increase in specific interactions with diverse functional groups of the surface, which may lead to increased adsorption and interaction caused by the quadrupole moment characteristic for asymmetrical molecular particles. Additionally, argon fills micropores $0.5 \div 1 \mathrm{~nm}$ in size at higher relative pressures $p / p_{0}$ compared to nitrogen at $77.4 \mathrm{~K}$, and because of faster diffusion, as a result of which the time periods necessary to reach the equilibrium are shorter. As a consequence, it is possible to test the micropores with sizes down to the minimum value of $0.5 \mathrm{~nm}$, using argon within the range of repetitive relative pressures, which considering the current modern and automated apparatuses are limited to $\sim 10^{-7}$. The advantage of using argon is clearly visible in the case of zeolites [11]. When using both argon and nitrogen, filling of ultra-micropores still occurs at very low pressures [8]. The problem of limited diffusion is also associated with low pressures, making it impossible for the molecular particles of the liquid to enter the narrowest micropores with diameters below $0.45 \mathrm{~nm}$. The use of (for instance) $\mathrm{CO}_{2}$ as an adsorbent in ambient temperatures presents a major advantage when testing ultra-micropores. Although the diameters of the molecular particles of $\mathrm{N}_{2}$, Ar and $\mathrm{CO}_{2}$ are similar, the molecular particles of $\mathrm{CO}_{2}$ may easily penetrate the micropores even at normal ambient temperatures. Because of these experimental advantages, adsorption with the use of $\mathrm{CO}_{2}$ has become a standard tool for the evaluation of microporous carbon [12]. However, due to the complex interactions of $\mathrm{CO}_{2}$ with $\mathrm{SiO}_{2}$, carbon dioxide is not used to characterise silica

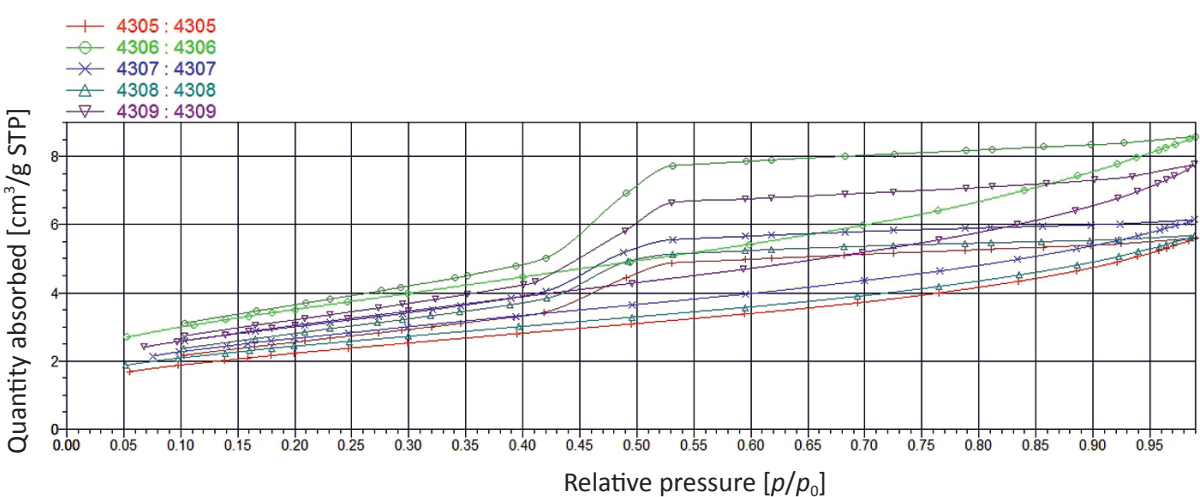

Fig. 5. An example of one of the linear isotherm plots - nitrogen at $77.4 \mathrm{~K}$ 


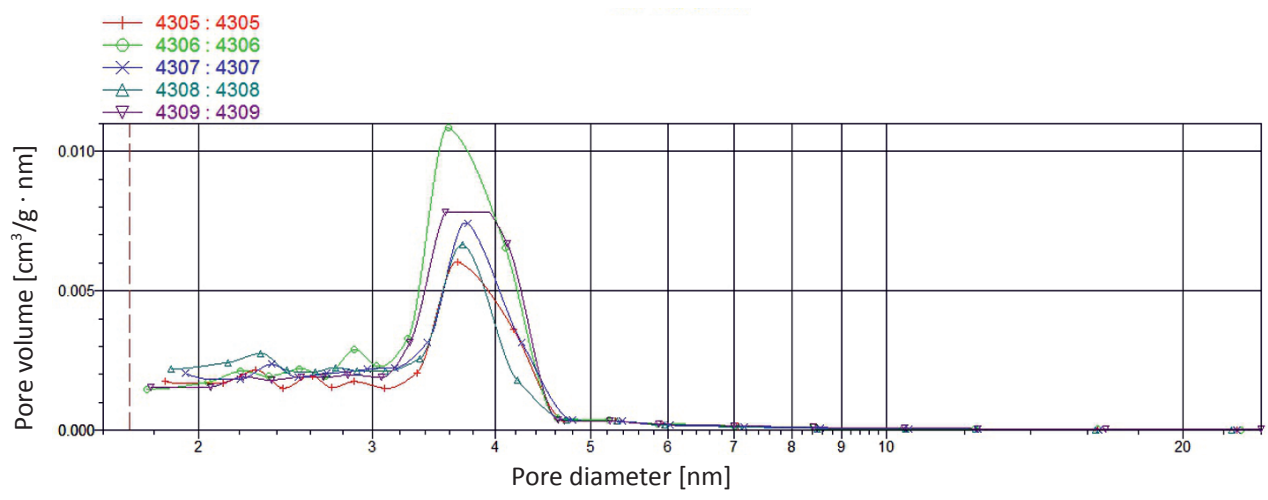

Fig. 6. BHJ desorption, $d V / d D$ pore volumes $-\mathrm{N}_{2}$ at $77.4 \mathrm{~K}$ for the selected samples 4305, 4306, 4307, 4308, 4309

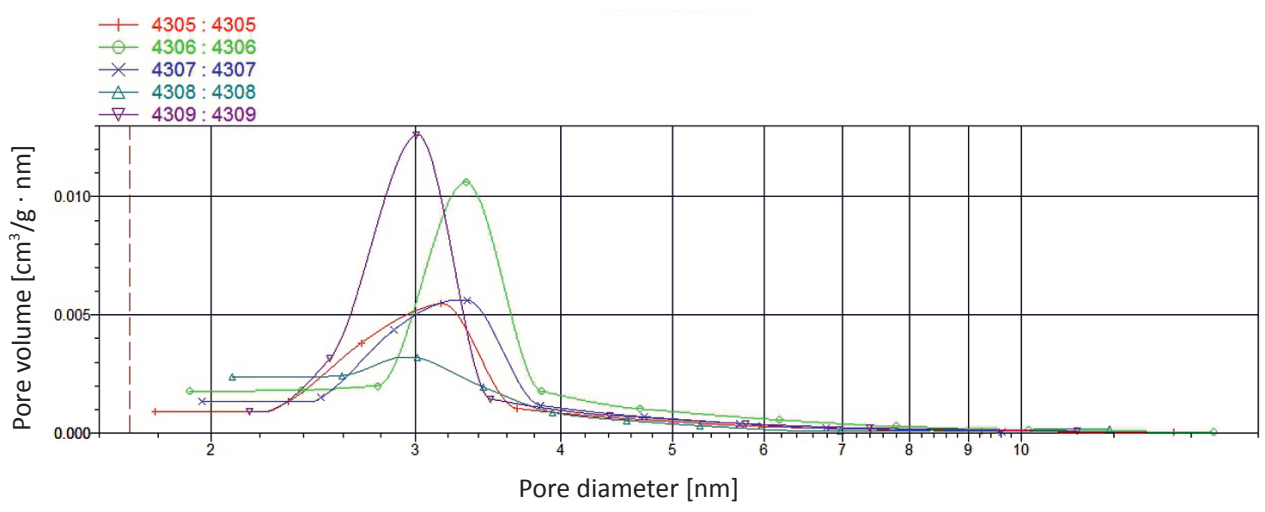

Fig. 7. BHJ desorption, $d V / d D$ pore volumes $-\mathrm{Ar}$ at $77.4 \mathrm{~K}$ for the selected samples 4305, 4306, 4307, 4308, 4309
The pore volume curves for the desorption of nitrogen $d V / d D$ were charted for 20 samples. An example of 5 selected curves is shown in Figures 6 and 7. The mutual comparison of plots in Figures 6 and 7 clearly shows that the curves in Figure 6 (nitrogen at $77.4 \mathrm{~K}$ ) are characterised by much better mutual autocorrelation compared to the curves in figure 7 (argon at $77.4 \mathrm{~K}$ ). The changes are visible not only in the adsorption part, with the relative pressure range $p / p_{0}$ of $0.7 \div 1.0$, but also in the desorption part, down to the drop of relative pressures below the value of $0.30 p / p_{0}$. The above mentioned behaviour of the isotherms may be a consequence of change in the state of matter from liquid to solid and vice versa. A comparison between Figures 6 and 7 shows that the corresponding maximum values of PSD for nitrogen at $77.4 \mathrm{~K}$ (Fig. 6) occur

and it differs considerably from the behaviour of nitrogen. The example of nitrogen adsorption presented in figure 5 has been selected for detailed analysis. Another, although much less visible differentiating behaviour is the fact that (when using the Tristar II 3020 device) the nitrogen isotherms always end the adsorption and begin the desorption at $p / p_{0} p_{0}=0.99$, while these values of relative pressure in the case of argon are more variable, and range between 0.98 and 1.01 (comparison of the right sides of Figs. 4 and 5). at pore diameters larger than the average maximum values of PSD for argon at 77.4 K (Fig. 7), when calculating these values from the desorption curves. The shapes of the curves in the case of nitrogen (Fig. 6) are inclined towards the lower pore diameters, indicating a more abrupt drop towards lower diameters, compared to their increase towards the maximum pore volume. In case of argon adsorption the situation is reversed. Using the DFT method, the distribution of pore sizes has been calculated for selected samples from 4305 to 4309 ,

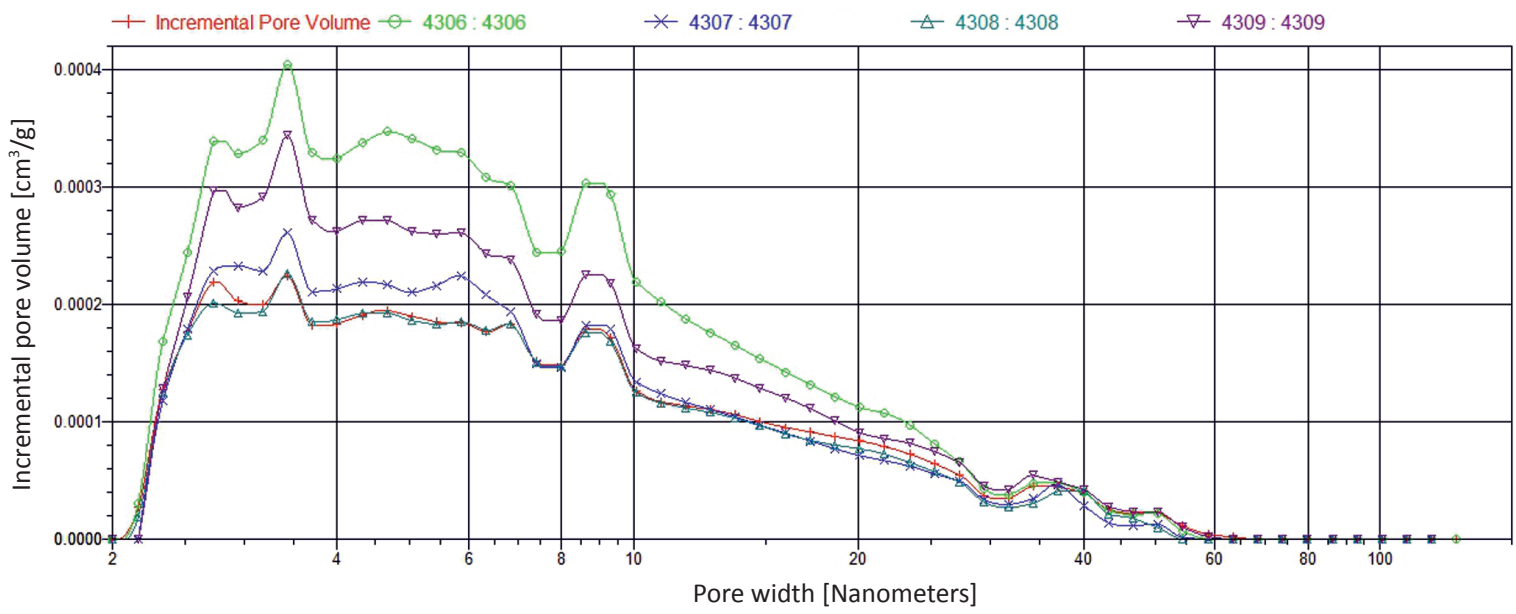

Fig. 8. A plot of the change in the increase of pore volume against the width of pores for samples $4305 \div 4309$ for nitrogen (the DFT method) 


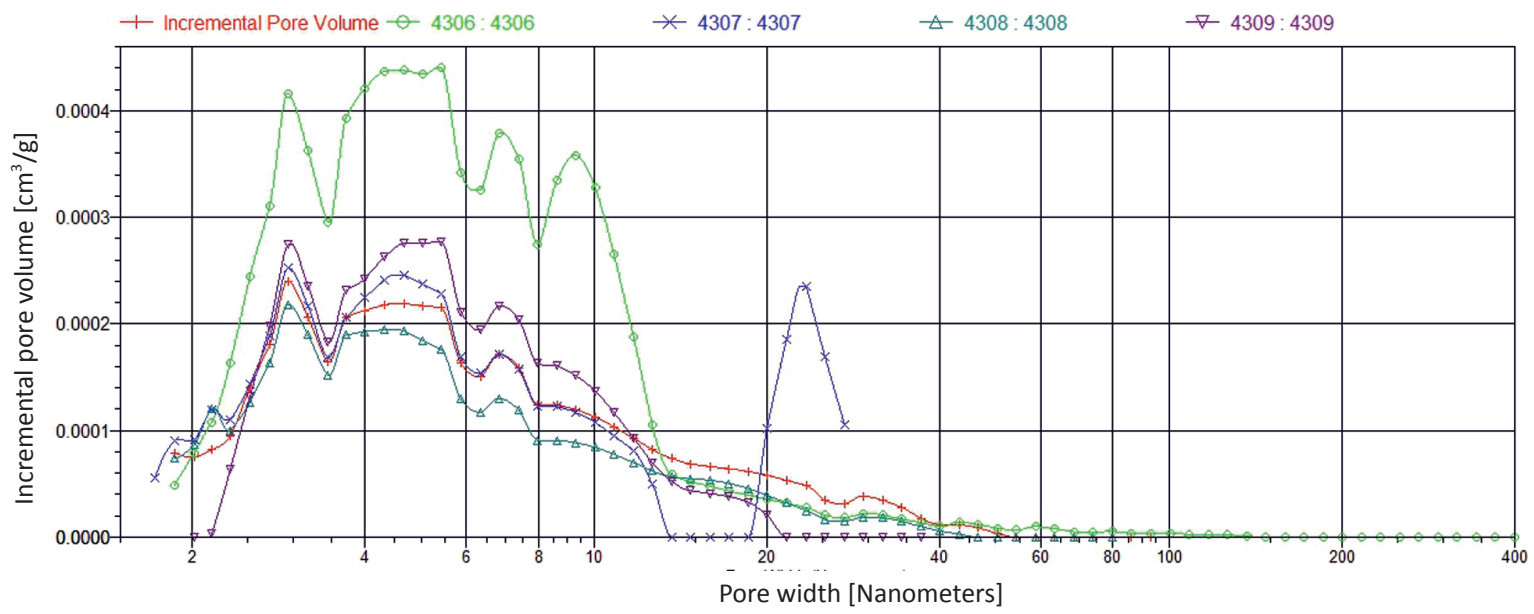

Fig. 9. A plot of the change in the increase of pore volume against the width of pores for samples $4305 \div 4309$ for argon (the DFT method)

along with the volume occupied by these pores in the studied samples, the results being presented in Figures 8 and 9. It is noted that the average diameter of pores for nitrogen and argon calculated using the DFT method exhibits minimal differences compared to the pores calculated by means of the BJH method. This result confirms the theory developed by Landers at al. [5] in which for pores $<4 \mathrm{~nm}$ the experimental hysteresis gradually decreases and the adsorption isotherm

Table 1. Experimental desorption data $-\mathrm{Ar}$ and $\mathrm{N}_{2}$ at $77.4 \mathrm{~K}$, and DFT (measurements for 20 samples from various depths)

\begin{tabular}{|c|c|c|c|c|c|c|c|c|}
\hline $\begin{array}{c}\text { Sample } \\
\text { no. }\end{array}$ & $\begin{array}{l}\text { Depth in } \\
{[\mathrm{m}]}\end{array}$ & $\begin{array}{c}\mathrm{BJH} \\
\mathrm{N}_{2} \text { des. at } \\
77 \mathrm{~K} \\
\text { diameter } \\
{[\mathrm{nm}]}\end{array}$ & $\begin{array}{c}\text { BJH } \\
\text { Ar des. at } \\
77 \mathrm{~K} \\
\text { diameter } \\
{[\mathrm{nm}]}\end{array}$ & $\begin{array}{c}\mathrm{BJH} \\
\text { difference } \\
\% \mathrm{~N}_{2} \text { to } \mathrm{Ar}\end{array}$ & $\begin{array}{c}\text { Diameter }[\mathrm{nm}] \\
\text { DFT } \\
\text { (incremental) } \\
\mathrm{N}_{2} \text { adsorption }\end{array}$ & $\begin{array}{c}\text { Volume DFT } \\
\text { (incremental) } \\
{\left[\mathrm{cm}^{3} / \mathrm{g}\right]}\end{array}$ & $\begin{array}{c}\text { Diameter [nm] } \\
\text { DFT } \\
\text { (incremental) } \\
\text { Ar adsorption }\end{array}$ & $\begin{array}{c}\text { Volume DFT } \\
\text { (incremental) } \\
{\left[\mathrm{cm}^{3} / \mathrm{g}\right]}\end{array}$ \\
\hline 4300 & 2834.15 & 3.78 & 3.01 & 25.6 & 3.44 & 0.0002180 & 2.95 & 0.0002370 \\
\hline 4301 & 2833.30 & 3.90 & 3.18 & 22.6 & 3.44 & 0.0003660 & 2.95 & 0.0004940 \\
\hline 4302 & 2832.30 & 3.93 & 3.20 & 22.8 & 3.44 & 0.0004210 & 2.94 & 0.22800000 \\
\hline 4303 & 2831.33 & 3.64 & 3.01 & 20.9 & 3.44 & 0.0002070 & 2.95 & 0.00023700 \\
\hline 4304 & 2829.75 & 3.96 & 3.30 & 20.0 & $2.73 \quad 3.43$ & 0.0001690 & 2.95 & 0.00024500 \\
\hline 4305 & 2828.42 & 3.66 & 3.15 & 16.2 & 3.44 & 0.0002240 & 2.95 & 0.00023900 \\
\hline 4306 & 2827.30 & 3.59 & 3.32 & 8.1 & 3.44 & 0.0004070 & $2.95 \quad 5.46$ & $0.000417 \quad 0.000440$ \\
\hline 4307 & 2826.53 & 3.72 & 3.27 & 13.8 & 3.44 & 0.0002580 & $2.95 \quad 4.61$ & 0.00024700 \\
\hline 4308 & 2825.53 & 3.71 & 3.01 & 23.3 & 3.44 & 0.0002250 & 2.95 & 0.00021900 \\
\hline 4309 & 2824.39 & 3.73 & 3.00 & 24.3 & 3.44 & 0.0003400 & $2.96 \quad 5.12$ & 0.00027700 \\
\hline 4310 & 2823.21 & 3.70 & 3.11 & 19.0 & 3.44 & 0.0002600 & $2.95 \quad 4.66$ & $0.000281 \quad 0.000304$ \\
\hline 4311 & 2822.43 & 3.54 & 3.00 & 18.0 & 3.44 & 0.0003070 & $2.94 \quad 4.56$ & $0.000358 \quad 0.000375$ \\
\hline 4312 & 2821.16 & 3.95 & 3.05 & 29.5 & 3.44 & 0.0003780 & $3.44 \quad 4.68$ & $\begin{array}{ll}0.000329 & 0.000371\end{array}$ \\
\hline 4313 & 2820.55 & 3.70 & 2.83 & 30.7 & 3.44 & 0.0003620 & $2.96 \quad 4.59$ & $0.000349 \quad 0.000373$ \\
\hline 4314 & 2819.21 & 3.68 & 3.11 & 18.3 & 3.44 & 0.0004230 & $2.95 \quad 4.57$ & $0.000344 \quad 0.000373$ \\
\hline 4315 & 2818.65 & 3.66 & 3.08 & 18.8 & 3.44 & 0.0004250 & $2.95 \quad 4.70$ & $0.000418 \quad 0.000484$ \\
\hline 4316 & 2817.63 & 3.68 & 3.17 & 16.1 & 3.44 & 0.0002770 & $2.93 \quad 4.42$ & $0.000260 \quad 0.000425$ \\
\hline 4317 & 2815.37 & 3.52 & 2.66 & 32.3 & 3.44 & 0.0002210 & $2.95 \quad 4.32$ & $0.000216 \quad 0.000242$ \\
\hline 4318 & 2814.85 & 3.71 & 2.91 & 27.5 & 3.44 & 0.0001710 & $2.95 \quad 3.70$ & $0.000142 \quad 0.000171$ \\
\hline 4319 & 2813.84 & 3.99 & 2.91 & 37.1 & 2.95 & 0.0010500 & 2.92 & 0.00010500 \\
\hline 4320 & 2811.29 & 3.61 & 3.07 & 17.6 & 3.44 & 0.0003560 & $2.95 \quad 4.68$ & $\begin{array}{ll}0.000280 & 0.000292\end{array}$ \\
\hline
\end{tabular}


overlaps the desorption isotherm, which corresponds to the equilibrated capillary condensation-evaporation transition. The conformance of the BJH (with the conventional Kelvin-
Cohan equation) and DFT methods for the size of pores in nanoscale is estimated practically and fits within the $\sim 4 \mathrm{~nm}$ range for the analysed samples.

\section{Summary}

The sum of all PSD results (for 20 samples) and the pore volumes occupied by them, calculated using both the BJH method (conventional Kelvin-Cohan equation) as well as the DFT method (for the adsorption of nitrogen and argon) is presented summarily in Table 1 . When analysing Table 1, it can be noticed that the average diameter of pores for nitrogen and argon calculated using the DFT method exhibits minimal differences, compared to the pores calculated using the $\mathrm{BJH}$ method. These minimal differences result from the minor impact of capillary condensation and adhesion, as well as the meniscus of liquid in the capillaries, along with the bridging effect for pore diameters below $4 \mathrm{~nm}$. A graphical presentation of the comparison between the BJH and DFT methods is visible in the Figures 8, 9. The incremental pore volume is the indicator which is taken into consideration, since it determines the volume of pores for the given range of diameters.

Please cite as: Nafta-Gaz 2016, nr 8, pp. 603-609, DOI: 10.18668/NG.2016.08.03

Article contributed to the Editor 14.01.2016. Approved for publication 27.04.2016.

Paper was written based on the statutory work called: Pore size distributions in "shale gas"-type deposits based on the analyses of adsorption isotherms - the work of INiG - PIB as ordered by MNiSW; arch. no.: DK-4100-76/15, order no.: 76/SG/15.

\section{Literature}

[1] Ciechanowska M. (ed.): Rzeczpospolita tupkowa: studium wiedzy o gazie z formacji łupkowych. Prace Naukowe Instytutu Nafty i Gazu 2012, no. 183, pp. 431-436.

[2] Dudek L. Włodarczyk M.: Pragmatyczne podejście do adsorpcji w skałach tupkowych złóż typu shale gas. Nafta-Gaz 2014, no. 7, pp. 416-424.

[3] Haynes W. M. (ed.): CRC Handbook of Chemistry and Physics (92nd ed.). Boca Raton, Florida: CRC Press 2011, 4.121 p.

[4] Kuila U., Prasad M.: Specific surface area and pore-size distribution in clays and shale. Geophysical Prospecting 2013, vol. 61, pp. 341-362.

[5] Landers J., Yu G., Neimark A. V.: Density functional theory methods for characterization of porous materials. Colloids and Surfaces A. Physicochemical and Engineering Aspects 2013, vol. 437, pp. 3-32.

[6] Lastoskie C., Gubbins K. E., Quirke N. N.: Pore-size distribution analysis of microporous carbons a density-functional theory approach. The Journal of Physical Chemistry 1993, vol. 97, pp. 4786-4796.

[7] Neimark A. V., Ravikovitch P. I.: Capillary condensation in MMS and pore structure characterization. Microporous and Mesoporous Materials 2001, vol. 44, pp. 697-707.

[8] Poprawa P., Kiersnowski H.: Perspektywy poszukiwań złóż gazu ziemnego w skałach ilastych (shale gas) oraz gazu ziemnego zamkniętego (tight gas) w Polsce. Biuletyn Państwowego Instytutu Geologicznego 2008, vol. 429, pp. 145-152.
[9] Sing K. S. W., Everett D. H., Haul R. A. W., Moscou L., Pierotti R. A., Rouquerol J., Siemieniewska T.: Reporting Physisorption Data of Gas/Solid Systems with Special Reference to the Determination of Surface Area and Porosity (Recommendations 1984). Pure Applied Chemistry 1985, vol. 57, 603 p.

[10] Such P.: Co to wtaściwie znaczy porowatość skat tupkowych. Nafta-Gaz 2014, no. 7, pp. 411-415.

[11] Thommes M.: Textural characterization of zeolite and ordered mesoporous materials by physical adsorption. Studies in Surface Science and Catalysis 2007, vol. 168, pp. 495-525.

[12] Thommes M., Cychosz K. A. Neimark A. V.: Advanced Physical Adsorption Characterization of Nanoporous Carbons. [in:] Tascon J. M. D. (eds.): Novel Carbon Adsorbents. Elsevier 2012, pp. 107-145.

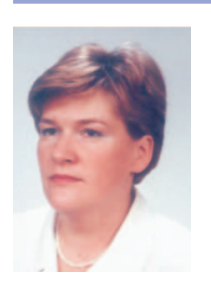

Mgr inż. Lidia DUDEK

Starszy specjalista badawczo-techniczny w Zakładzie Geologii i Geochemii.

Instytut Nafty i Gazu - Państwowy Instytut Badawczy ul. Lubicz 25 A

31-503 Kraków

E-mail: lidia.dudek@inig.pl 